\title{
Gambaran Limfoma Burkitt di Departemen IImu Kesehatan Anak RSUP Gipto Mangunkusumo Jakarta
}

\author{
Selvi Nafianti*, Endang Windiastuti**, Djajadiman Gatot** \\ * Departemen Ilmu Kesehatan Anak FK USU/RSUP H.Adam Malik, Medan \\ **Departemen Ilmu Kesehatan Anak FKUI/RS Dr. Cipto Mangunkusumo, Jakarta
}

\begin{abstract}
Latar belakang. Limfoma Burkitt merupakan bentuk keganasan pada anak yang jarang ditemukan dibandingkan keganasan lain. Angka kematian limfoma Burkitt sangat tinggi, namun prognosis menjadi sedikit lebih baik karena banyak pilihan kemoterapi.

Tujuan. Mengetahui gambaran limfoma Burkitt pada anak di RSUPN Cipto Mangunkusumo Jakarta. Metode. Penelitian dilakukan secara retrospektif dengan mengambil data dari rekam medik Divisi Hematologi-Onkologi RSUPN Cipto Mangunkusumo periode Januari 2001 hingga Desember 2006. Semua pasien yang datang ke Poliklinik rawat jalan dan ruang rawat inap dengan diagnosis Limfoma Burkitt diikutsertakan dalam penelitian.

Hasil. Tercatat 7 kasus limfoma Burkitt, terdiri dari 6 laki-laki dan 1 perempuan. Usia termuda 1 tahun 5 bulan sedangkan usia tertua 14 tahun 10 bulan. Enam kasus mendapat kemoterapi, yaitu 4 kasus mendapat kemoterapi dan operasi 2 kasus. Dari 7 kasus yang tercatat satu orang meninggal dunia.

Kesimpulan. Limfoma Burkitt adalah penyakit keganasan pada anak yang jarang ditemukan. (Sari Pediatri 2008;10(1):47-52).
\end{abstract}

Kata Kunci: limfoma Burkitt, starry sky, kemoterapi, endemik

L imfoma Burkitt termasuk ke dalam subgrup limfoma non-Hodgkin agresif, mempunyai daya gradasi tinggi dan terbentuk dari sel kecil, tidak membelah (noncleaved), tidak berdiferensiasi, difus dan berasal dari limfosit B. Pemberian nama limfoma Burkitt merujuk kepada penemu penyakit yaitu Denis Parsons Burkitt, yang

Alamat Korespondensi:

Dr Endang Windiastuti, Sp.A(K) Divisi Hematologi. Departemen Ilmu Kesehatan Anak FKUI-RSCM. Jl. Salemba no. 6, Jakarta 10430.

Telepon: 021-3907744, 31901170 Fax.021-3913982. memetakan distribusi geografis penyakit ini di Afrika. Penyakit ini merupakan neoplasma sel beta dengan laju pertumbuhan tinggi, mempunyai dua bentuk, yaitu bentuk endemik (tipe Afrika) dan bentuk nonendemik (sporadik). ${ }^{1-6}$

Limfoma Burkitt (LB) merupakan bentuk keganasan pada anak yang jarang ditemukan. ${ }^{1,2,3} \mathrm{Di}$ Amerika Serikat, dilaporkan 100 kasus baru per tahun, sedangkan insidens di Afrika berada di sekitar 100 per satu juta anak. ${ }^{7-10}$ Limfoma Burkitt endemis di antara orang-orang yang tinggal di daerah Afrika Tengah, 
sementara bersifat sporadis pada penduduk Amerika. Insidens pada anak laki-laki dibanding perempuan 23:1, limfoma Burkitt lebih sering pada anak-anak usia 7 tahun, sementara di luar Afrika usia rata-rata penderita 11 tahun. Angka kematian limfoma Burkitt sangat tinggi, biasanya pasien meninggal sangat cepat. Pada saat ini, prognosis menjadi sedikit lebih baik karena banyak pilihan kemoterapi. Terapi agresif menjadi pilihan di beberapa sentra penelitian. ${ }^{1,2}$

Secara mikroskopis, limfoma Burkitt dikenali dengan adanya gambaran seperti bintang di langit (starry sky) yang juga dapat terlihat pada limfoma dengan proliferasi sangat tinggi, diselubungi makrofag yang berserakan dengan fagosit sel debris. ${ }^{1,2,6}$ Virus Epstein-Barr (VEB) diduga berperan besar terjadinya tipe Afrika, sementara hubungannya dengan tipe sporadik masih belum jelas. VEB dihubungkan dengan sekitar 20\% kasus sporadik. ${ }^{3,5,11-15}$

Gejala klinis limfoma Burkitt pada awalnya hanya dikenali dengan pembesaran kelenjar getah bening tanpa rasa sakit dan tumbuh dengan cepat pada leher, sela paha, di bawah rahang atau bisa juga di bawah tangan. Pada tipe sporadik, benjolan dimulai pada daerah pusat atau perut. Pemeriksaan penunjang meliputi biopsi kelenjar getah bening, foto sinar-X dada, aspirasi sumsum tulang, CT-scan, analisa cairan serebrospinal dan lain-lain. Kemoterapi menjadi pilihan utama pengobatan, antara lain prednison, siklofosfamid, vinkristin, sitarabin, doksorubisin, dan metotreksat. Radioterapi tidak banyak dipergunakan dalam tatalaksana limfoma Burkitt. ${ }^{16-20}$

Data mengenai limfoma Burkitt di Indonesia masih sangat sedikit sehingga dilakukan penelitian ini untuk mengetahui gambaran limfoma Burkitt pada anak di RSUPN Cipto Mangunkusumo Jakarta.

\section{Metode}

Penelitian dilakukan retrospektif dengan mengambil data dari rekam medik Divisi Hematologi-Onkologi RSUPN Dr. Cipto Mangunkusumo Jakarta periode Januari 2001 hingga Desember 2006. Semua pasien yang datang ke Poliklinik rawat jalan dan ruang rawat inap dengan diagnosis Limfoma Burkitt diikut sertakan dalam penelitian. Data demografi pasien yaitu usia, jenis kelamin, status gizi. Pemeriksaan fisik dinilai lokasi benjolan, hasil pemeriksaan histopatologi dan pemeriksaan penunjang ultrasonografi, $C T$-scan dan foto dada, komplikasi yang berhubungan dengan lokasi benjolan, staging, pengobatan, jenis serta jumlah siklus kemoterapi yang diberikan dan hasil akhir pengobatan.

\section{Hasil}

Dari hasil penelusuran rekam medik periode Januari 2001 sampai dengan Desember 2006 didapat 7 kasus yang diagnosis dengan Limfoma Burkitt. Terdiri dari 6 kasus laki-laki dan perempuan pada 1 kasus. Berdasarkan CDC 2000 terdapat dua kasus menderita gizi buruk dan satu kasus dengan obesitas. Usia termuda dari kasus yang tercatat adalah 1 tahun 5 bulan sedangkan usia tertua pada usia 14 tahun 10 bulan (Tabel 1).

Sebagian besar kasus Limfoma Burkitt datang dengan keluhan utama adanya benjolan yang disadari keluarga pada hitungan minggu hingga 6 bulan. Tidak dijumpai keluhan nyeri ataupun lesi pada tulang. Empat kasus adalah rujukan dari Departemen Bedah Anak dan THT dan telah dilakukan operasi

Table 1. Karakteristik klinis Limfoma Burkitt di RSUP Dr. Cipto Mangunkusumo Jakarta

\begin{tabular}{lc}
\hline Karakteristik & Jumlah $(\mathrm{n}=7)$ \\
\hline Usia (tahun) & 3 \\
$0-<5$ & 3 \\
$5-<10$ & 1 \\
$10-<15$ & \\
Jenis kelamin & 6 \\
Laki - laki & 1 \\
Perempuan & \\
Status Gizi & 2 \\
Buruk & 1 \\
Kurang & 3 \\
Baik & 1 \\
Obesitas & \\
Lokasi benjolan & 1 \\
Leher & 1 \\
Pipi & 2 \\
Bawah telinga & 2 \\
Abdomen & 1 \\
Testis & 2 \\
Lama keluhan benjolan (bulan) & 4 \\
$<1$ & 1 \\
$1-3$ & \\
$>3$ & \\
\hline
\end{tabular}


pada 4 kasus tetapi mengalami kekambuhan sehingga pasien dirujuk ke Departemen Ilmu Kesehatan Anak. Pada Limfoma Burkitt terjadi komplikasi tergantung organ yang terlibat atau lokasi terdekat massa dengan organ. Hidronefrosis pada 1 kasus akibat penekanan pada ureter dan 1 kasus terjadi kebutaan. Tiga pasien mengeluh konstipasi dengan benjolan pada daerah abdomen (Tabel 2).

Hasil pemeriksaan PA pada penelitian ini didapatkan 6 dengan gambaran starry sky dan 1 kasus dengan Limfoma malignum non Hodgkin difus tipe burkitt's derajat keganasan tinggi. Tiga pasien datang dalam stadium II dan 4 dalam stadium III. Pada sebagian kasus telah dilakukan pemberian kemoterapi sesuai dengan protokol yang dipakai di Divisi Hemato-

Tabel 2. Komplikasi Limfoma Burkitt menurut lokasi benjolan

\begin{tabular}{lc}
\hline Komplikasi & Jumlah $(\mathrm{n}=7)$ \\
\hline Hidronefrosis & 1 \\
Buta & 1 \\
Retensi urin & 1 \\
Konstipasi kronis & 3 \\
Suara hilang & 1 \\
\hline
\end{tabular}

Tabel 3. Staging, pengobatan dan hasil pemantauan

\begin{tabular}{lc}
\hline Pengobatan dan hasil & Jumlah $(\mathrm{n}=7)$ \\
\hline Staging & 0 \\
I & 3 \\
II & 4 \\
III & 0 \\
IV & \\
Pengobatan & 1 \\
Belum dapat pengobatan & 4 \\
Kemoterapi & 1 \\
Kemoterapi + enukleasi & 1 \\
Kemoterapi + orkhidektomi & \\
Siklus kemoterapi (kali) & 1 \\
$<1$ & 3 \\
1-5 & 2 \\
$>5$ & \\
Hasil pemantauan pasien & 1 \\
Masih dalam pengobatan & 5 \\
Drop out & 0 \\
Sembuh & 1 \\
Meninggal &
\end{tabular}

Onkologi Departemen IKA FKUI. Dari 7 kasus yang diteliti, 6 kasus mendapat kemoterapi yang terdiri dari kemoterapi saja pada 4 kasus serta kemoterapi dan operasi pada 2 kasus. Sayangnya 5 dari tujuh kasus tidak melanjutkan pengobatan dengan alasan yang tidak jelas. Satu kasus belum pernah mendapat pengobatan sama sekali karena keluarga menolak, dan akhirnya meninggal dunia. Jenis kemoterapi yang diberikan dan cara pemberian adalah prednisolon $(60 \mathrm{mg} / \mathrm{m} 2 /$ hari) selama 14 hari, Ara-C $250 \mathrm{mg} / \mathrm{m} 2 /$ hari melalui infus terus menerus pada hari 7, 8 dan 9. Metotreksat + Ara-C + Deksametason secara intratekal pada hari 1, 4, 14, 17 dan 28. Siklofosfamid I.V dosis 1000 $\mathrm{mg} / \mathrm{m} 2$ diberikan pada hari 1, 14 dan 28 . Vinkristin $1.4 \mathrm{mg} / \mathrm{m} 2$ I.V pada hari $1,14,28$. Metotreksat 500 $\mathrm{mg} / \mathrm{m} 2 \mathrm{I} . \mathrm{V}$ hari 2, 3, 15, 16, 29 dan 30.

Lama pengamatan pada penelitian ini antara 1 bulan sampai 6 bulan. Terdapat satu kasus masih mendapat kemoterapi dan datang kontrol sesuai jadwal hingga akhir penelitian menunjukkan respon terapi yang baik namun belum bisa dikatakan sembuh karena masih terdapat massa tumor walaupun terjadi pengecilan. Pada satu kasus lain dijumpai adanya respon yang baik terhadap kemoterapi ditandai dengan pengecilan massa tumor pada saat hari ke 4 pemberian kemoterapi, sayangnya pasien ini hanya menerima kurang dari satu siklus dan tidak melanjutkan kemoterapi sampai selesai. Satu kasus direncanakan untuk diberikan radioterapi, karena tidak dijumpainya respon terhadap kemoterapi tetapi keluarga pasien menolak. Tiga kasus mendapat kemoterapi tetapi tidak diketahui respon terapi karena data tentang massa tumor tidak tercatat dengan baik. Satu kasus menolak mendapatkan kemoterapi dan meninggal oleh karena sepsis.

\section{Diskusi}

Untuk menegakkan diagnosis pasti limfoma Burkitt dilakukan pemeriksaan histopatologi, dan untuk mencari metastasis serta menentukan staging perlu dilakukan BMP dan beberapa pemeriksaan imaging. Kuttler dkk, ${ }^{7}$ dalam penelitian mereka mendapatkan bahwa hasil pemeriksaan histopatologi sebanyak $80 \%$ menunjukkan gambaran starry sky. Gambaran starry sky sesuai dengan hasil yang didapat pada 6 dari 7 kasus yang tercatat. Fowles dkk, ${ }^{8}$ melakukan penelitian di Uganda, mendapatkan beberapa pasien LB mengalami lesi pada tulang panjang dan pelvis. Tempat yang sering 
terkena adalah paha, tibia, metafisis daerah lutut. Pada kaki lesi biasanya bilateral dan simetris. Lima pasien mengalami patah tulang patologis. Pada penelitian ini tidak dijumpai lesi pada tulang.

Pada penelitian ini tidak dapat dijelaskan hubungan infeksi dengan limfoma Burkitt. Sementara, Heath $\mathrm{dkk},{ }^{12}$ melaporkan kemungkinan infeksi sebagai penyebab leukemia dan limfoma pada anak, dan insidens meningkat setelah terjadi pertambahan heterogenitas penduduk di suatu daerah. Pada satu daerah dengan pertumbuhan penduduk yang tinggi sering terjadi kelompok LB, dan penyakit tersebut sering muncul pada saat yang sama. de-The G dkk, ${ }^{9}$ membuktikan secara epidemiologi bahwa titer antibodi Virus Epstein Barr (VEB) yang tinggi meningkatkan risiko terkena $\mathrm{LB}$. Boss $\mathrm{dkk},{ }^{13}$ menyatakan dalam penelitiannya bahwa pada kasus LB yang berkelompok pada suatu daerah erat hubungannya dengan infeksi VEB. Rao dkk, ${ }^{14}$ melaporkan bahwa subtype VEB pada satu daerah akan berbeda dengan daerah lain walaupun gejala klinisnya sama dan risiko terhadap terjadinya VEB sama walau dengan subtiope VEB yang berbeda. Fujita dkk, ${ }^{15}$ menyatakan bahwa gambaran starry sky timbul terutama pada LB yang ada hubungannya dengan infeksi VEB. Pada penelitian kami terdapat 6 kasus dengan gambaran starry sky, sayangnya tidak dilakukan pemeriksaan lanjutan untuk membuktikan adanya infeksi VEB. Seharusnya dilakukan pemeriksaan serologi virus VEB dan kultur darah untuk mengetahui virus penyebab.

Koksal dkk, ${ }^{10}$ melaporkan satu kasus LB dengan keluhan benjolan pada alis mata sebelah kiri, di dekat telinga dan di rahang bawah kiri serta ditemukan keterlibatan paru dan ginjal. Setelah kemoterapi diberikan, benjolan di alis mata menghilang dan keluhan di paru dan ginjal menghilang. Kasus LB jarang melibatkan alis mata dan paru. Kasus di RS Dr. Cipto Mangunkusumo mempunyai gejala yang menonjol adanya benjolan pada bagian bawah telinga dan abdomen, hanya satu kasus terjadi kebutaan walaupun tidak terlihat adanya benjolan di sekitar mata.

Pada penelitian ini telah dilakukan operasi pada 4 kasus, setelah terjadi kekambuhan baru diketahui pasien menderita LB. Dilek dkk, ${ }^{11}$ melaporkan satu kasus limfoma Burkitt yang didiagnosis sebagai suatu abses gigi, sehingga dia mengingatkan para dokter gigi untuk mempertimbangkan limfoma Burkitt pada kasus-kasus gusi bengkak dan tidak terfokus pada kelainan gigi saja. Stadium penyakit harus diketahui segera untuk memberikan prognosis yang lebih baik. Miron ${ }^{16} \mathrm{dkk}$ menjelaskan karena pada kasus LB lanjut, diagnosis dapat ditegakkan dengan fine-needle aspiration. Penyembuhan dengan kemoterapi mencapai $80 \%$, maka tidak perlu dilakukan pembedahan awal kecuali bila keadaan emergensi akut. Lebih jauh, laparotomi yang dilakukan dapat memperlambat pemberian kemoterapi dan mengurangi laju kesintasan. Gasparini $\mathrm{dkk}^{17}$ memberikan kemoterapi intensif singkat pada penderita LB lanjut dan menyimpulkan bahwa pemberian kemoterapi intensif singkat dapat menyembuhkan banyak pasien LB lanjut. Pada seri kasus kami tidak dapat diketahui manfaat kemoterapi karena umumnya penderita tidak mengikuti kemoterapi sampai selesai, meskipun respon awal terlihat baik.

Todeschini dkk, ${ }^{18}$ melakukan penelitian dengan menggunakan protokol anak untuk pasien dewasa dan mendapatkan prognosis LB dewasa lebih baik. Tidak dijumpai perbedaan yang bermakna hasil pengobatan LB pada dewasa dan anak, dan hasil yang dicapai sama antara leukemia dengan limfoma. Namun pada LB dewasa lebih sering timbul infeksi sekunder. Relaps terjadi pada masa 8 bulan pengobatan atau tidak ada sama sekali. Pada beberapa kasus, walaupun telah diobati selama 36 bulan tetapi belum dijumpai tanda-tanda relaps. Secara klinis pada LB yang tidak segera diobati, perjalanan penyakit sangat progresif, dengan penyebaran cepat dan diikuti kematian.

Revesz $\mathrm{dkk},{ }^{19}$ melaporkan kasus limfoma Burkitt relaps pada seorang anak laki-laki usia 8 tahun yang mengalami masalah metabolisme kompleks, termasuk diabetes insipidus renal dan asidosis laktat berat. Keadaan asidosis laktat tersebut merupakan respon sementara terhadap kemoterapi dan radioterapi tetapi bukan akibat pemberian bikarbonat atau tiamin. Tacyildiz dkk, ${ }^{20}$ menyatakan jika ditemukan kadar CD44 dalam serum tinggi pada saat diagnosis dihubungkan dengan prognosis jelek dan memberikan hasil yang tidak menggembirakan pada anak dengan leukemia dan limfoma. Pada penelitian ini tidak dilakukan pemeriksaan kadar CD44.

Prognosis lebih baik pada anak usia muda pada saat diagnosis, ukuran tumor kecil dan segera diberikan kemoterapi, hal ini menunjukkan pentingnya diagnosis dan pengobatan yang lebih dini. Laju kesintasan diperhitungkan berdasarkan letak dan penyebaran tumor, 
jika sumsum tulang dan SSP terlibat maka prognosis menjadi buruk. LB sangat sensitif terhadap kemoterapi dan pasien dengan penyakit yang masih terbatas dan bersifat lokal (stadium 1 dan 2) diharapkan penyembuhan berkisar anatara 90-100\% dengan pemberian kemoterapi. Tidak seperti limfoma lain, terapi radiasi pada LB tidak memperbaiki prognosis. Sayangnya pada penelitian ini tidak dapat diketahui prognosis dan hasil pengobatan karena pasien tidak melanjutkan pengobatan sampai selesai.

\section{Kesimpulan}

Limfoma Burkitt merupakan bentuk keganasan pada anak yang jarang ditemukan dibanding keganasan lain. Angka kematian limfoma Burkitt sangat tinggi, pada umumnya pasien meninggal sangat cepat. Pada saat ini, prognosis menjadi sedikit lebih baik karena banyak pilihan kemoterapi. Terapi agresif menjadi pilihan di beberapa sentra penelitian.

\section{Daftar Pustaka}

1. Magrath I: Malignant non-Hodgkin's lymphomas in children. Dalam: Pizzo PA, Poplack DG, penyunting. Principles and Practice of Pediatric Oncology. Philadelphia: JB Lippincott; 4nd ed., 2002. pp 681705 .

2. Cavdar AO, Gozdasoglu S, Yavuz G. Burkitt's lymphoma between African and American types in Turkish children: Clinical, viral (EBV), and molecular studies. Med Pediatr Oncol 1993;21:36-42.

3. Richardson DH. Burkitt's lymphoma clusters in a Virginia community. Va Med 1977;104:19-21.

4. Tsui SHC, Wong MH, Lam WY. Burkitt's lymphoma presenting as mandibular swelling: Report of a case and review of publications. Br J Oral Maxillofac Surg 2000;38:8-11.

5. Hanazawa T, Kimura Y, Sakamaki H, Yamaguchi A, Nagumo M, Okano T. Burkitt's lymphoma involving the mandible. Report of a case and review of Japanese cases. Oral Surg Oral Med Oral Pathol 1998; 85: 21620.

6. Halperin W, Altman R, Stemhagen A. Epidemiologic investigation of clusters of leukemia and Hodgkin's diseasein Rutherford, New Jersey. J Med Soc N J 1980;77:267-73.
7. Kuttler F, Ame P, Clark H, Haughey C, Mougin C, Cahn JY, Dang CV, Raffeld M, Fest T. c-myc box II mutations in Burkitt's lymphoma-derived alleles reduce cell-transformation activity and lower response to broad apoptotic stimuli. Oncogene 2001 Sep 20;20:608494.

8. Fowles JV, Olweny CL, Katongole-Mbidde E, Lukanga-Ndawula A, Owor R. Burkitt's lymphoma in the appendicular skeleton. J Bone Joint Surg - Br 1983;65B: 464-71

9. de-The G, Geser A, Day NE, Tukei PM, Williams EH, Beri DP. Epidemiological evidence for causal relationship between Epstein-Barr virus and Burkitt's lymphoma from Ugandan prospective study. Nature 978;274:756-61.

10. Köksal Y, Reisli, Uçar C, Avunduk M, Açıkgözo lu S, Çalı kan Ü. A Burkitt's lymphoma case with eyelid, renal and pulmonary involvement. Turk J Pediatr 2006; 48: $181-4$.

11. Dilek A, Bozkaya S, Karaca I, Tokman B, Pinarli G. Childhood Craniofacial Burkitt's Lymphoma Presenting as Maxillary Swelling: Report of a Case and Review of Literature. J Dent Child 2006;73:45-50.

12. Heath CW. Community clusters of childhood leukemia and lymphoma: Evidence of infection? Am J Epidemiol 2005; 162:817-22.

13. Boss LP, Levine PH, Hanes RS. A cluster of young patients with Burkitt's lymphoma and nasopharyngeal carcinoma in central Texas. JAMA 1985;253:2843-46.

14. Rao CR, Gutierrez MI, Bhatia K, Fend F, Franklin J, Appaji L, Gallo G, O’Conor G, Lalitha N, Magrath I. Association of Burkitt's lymphoma with the Epstein-Barr virus in two developing countries. Leuk Lymphoma 2000;39:329-37.

15. Fujita S, Buziba N, Kumatori A, Senba M, Yamaguchi A, Toriyama K Early stage of Epstein-Barr virus lytic infection leading to the "starry sky" pattern formation in endemic Burkitt lymphoma. Arch Pathol Lab Med. 2004;128:549-52.

16. Miron I, Frappaz D, Brunat-Mentigny M, Combaret V, Buclon M, Bouffet E. Initial management of advanced Burkitt lymphoma in children: is there still a place for surgery? Pediatr Hematol Oncol 1997;14:555-61.

17. Gasparini M, Rottoli L, Massimino M, Gianni MC, Ballerini E, Ravagnani F. Curability of advanced Burkitt's lymphoma in children by intensive short-term chemotherapy. Eur J Cancer 1993;29A:692-8.

18. Todeschini G, Tecchio C, Degani D, Meneghini V, Marradi P, Balter R. Eighty-one percent event-free survival in advanced Burkitt's lymphoma/leukemia: no differences in outcome between pediatric and 
adult patients treated with the same intensive pediatric protocol. Ann Oncol 1997;8 Suppl 1:77-81.

19. Revesz T, Obeid K, Mpofu C. Severe lactic acidosis and renal involvement in a patient with relapsed Burkitt's lymphoma. Ped Hematol Oncol 1995;6:10-5.
20. Tacyildiz N, Cavdar AO, Yavuz G, Gozdasoglu S, Unal E, Ertem U. Serum levels and differential expression of CD44 in childhood leukemia and malignant lymphoma: correlation with prognostic criteria and survival. Pediatr Int 2001; $43: 354-60$. 